\title{
1. Theory of institutional reform and government structure
}

\subsection{INTRODUCTION}

As noted in the Introduction, globalization entails a controversy over the appropriate policy authority allocation between bureaucratic delegation for adaptation and political command for coordination. The controversy has resonated in the terrains of Japanese politics and political science. Because Japan is a state with limited natural resources, it is highly dependent on international commerce for its economic prosperity. Consequently, Japan is extremely sensitive to the problem of adjustment to the international order that regulates cross-border economic transactions. Due to its non-liberal legacy, adjustment to a liberal international order has been and continues to be a major policy and political problem for Japan.

Until recently, many studies on the Japanese political economy (Patrick and Rosovsky, 1976; Aoki, 1983; Aoki and Dore, 1994) analyzed institutional stability and maintenance by focusing primarily on cooperation among relevant economic actors in supporting the existing economic institution, which is known as the Japanese-style coordinated market economy (CME). It is widely acknowledged that the Japanese-style CME generated remarkable economic growth with stable employment during the postWorld War II period from the early 1950s through the late 1980s. However, since the early 1990s, it has not fared well under the neoliberal global economic order where the keys to prosperity are competition, openness, and innovation as opposed to cooperation, control, and fine-tuning.

More recently, believing that institutional maintenance is no longer appropriate, reformist political and bureaucratic officials have tried to change the CME institution, the public policy domains, and even the authority allocation scheme. The scope of the changes is immense with regard to the beliefs and behaviors of politicians, bureaucrats, business managers, workers, and citizens about the role of government in the market as well as the institutions that encompass the relationships between government and markets, between banks and firms, and between managers and workers. Accordingly, institutional reform entails conflicts and compromises, and is highly contentious and deeply politicized. 
The sources of conflict are informational and distributive, contained in the games of assurance and coordination, respectively. Accordingly, solving these problems requires adaptation and coordination mechanisms, which are facilitated by bureaucratic delegation and political command, respectively.

In this chapter, I develop a normative analysis that sets the stage for the positive and empirical analysis in the subsequent chapters. Specifically, I try to address the following questions: What is an institution? Why is it difficult to change an institution? How can an institution be changed? What are the roles of government in facilitating institutional reform? Why does policy authority allocation matter?

This chapter is structured as follows. Section 1.2 looks at two problems of institutional reform: institutions and institutional bundling, and globalization and institutional rebundling; Section 1.3 examines two mechanisms of adjustment: adaptation through information transmission, and coordination through Coasian bargaining; Section 1.4 develops an analytical framework that relates the appropriate authority allocation to the relationship between agencies' tasks; Section 1.5 concludes.

\subsection{TWO PROBLEMS OF INSTITUTIONAL REFORM}

\subsubsection{Institutions and Institutional Bundling}

According to Greif (2006, p. 39), institutions are 'a system of interrelated rules, beliefs, norms, and organizations'. Rules specify normative behavior and provide a shared cognitive system, coordination, and information, whereas beliefs and norms provide the motivation to follow them. For North (1990, p. 3), 'institutions define the incentive structure of a society'. The institutional rules determine the kinds of economic activities that will be profitable and viable as well as shape the adaptive efficiency of firms and other organizations via rules that regulate entry, governance structures, and the flexibility of organizations. In particular, rules to encourage the development and utilization of tacit knowledge, and therefore creative entrepreneurial talent, are important.

For instance, Japan's institutions in the post-World War II period entail a bundle of private arrangements (Aoki, 2001; Whittaker and Deakin, 2009). These are outlined as follows:

- Main bank system, through which commercial banks provide their client firms with long-term loans (also known as 'patient capital') and external oversight for investment and managerial efficiency. 
- Manager-centric or contingent corporate governance, in which firm managers are recruited from firms' rank-and-file workforces and execute long-term business plans by which they provide their fellow workers with long-term employment.

- Long-term employment practices and limited mid-career job markets incentivize workers to acquire firm-specific loyalty and skills suitable for fine-tuning and product differentiation, and are the source of Japanese firms' competitive advantage.

- Integrated industrial networks and cross-stockholding are arrangements of reciprocal stockholding between firms that create horizontal and vertical industrial networks, reducing risks of hostile takeover and maintaining manager-centric corporate governance with limited stockholders' influence.

All of these arrangements constitute the Japanese-style market economy, referred to as 'stakeholder capitalism' or a 'coordinated market economy' (CME). CME embraces the interests of stakeholders, including the main bank officials, corporate managers, regular employees, suppliers, and other affiliated firms, rather than those of stockholders in the sense of Dore (2000). In addition, CME relies upon organizations, rather than markets, for nurturing specific human assets in the sense of Williamson (1985). Thus, it differs from 'stockholder capitalism' or a 'liberal market economy' (LME) with market-consistent arrangements, including (1) stock issuance; (2) committee system with independent external directors; (3) flexible labor markets; and (4) flexible corporate structures via organizational splits, mergers and acquisitions.

An institution rarely stands alone for two reasons. First, an institution is internally coherent. Private arrangements in one domain are related closely to those in others, constituting 'institutional bundling' or 'complementarity'. In the case of Japanese CME, the main bank system and crossstockholding are closely related to manager-centric corporate governance and long-term employment.

Second, an institution is embedded within the linkage between private arrangements and public policy domains. A policy domain is defined as a set of public policy programs for a specific industrial sector or function that incentivize related private agents to improve the efficiency of their economic production or transaction, in the sense of Shonfield (1965). A state's economy includes a multitude of policy domains, each of which needs to be consistent with other domains to make the state's economic institutions coherent, efficient, and compatible with the prevailing international order. Each policy domain is administered by a bureaucratic organization of competence that: 
$\mathrm{ha}[\mathrm{s}]$ three interrelated roles, to produce and disseminate rules, perpetuate beliefs and norms, and to influence the set of feasible behavioral beliefs... Institutions generate behavior, rules correspond to the beliefs and norms that motivate it, while organizations contribute to this outcome in the manner mentioned previously. (Greif, 2006, p. 37)

Specifically, public policy domains pertaining to the present analysis of the Japanese-style CME include bank law, the Commercial Code (Shoho), antimonopoly law, labor law, the pension system, trade law, foreign exchange law, and so forth. The following bureaucracies are assigned to administer the related public policy domains with the specified roles:

- The Ministry of Finance (MOF) provides commercial banks with low interest-rate environments, segmented competition, and informal bailout guarantees with which the banks secure regulatory rents and offer patient capital to firms.

- The Ministry of International Trade and Industry (MITI, currently the Ministry of Economy, Trade and Industry [METI]) controls the Commercial Code and antimonopoly laws to permit an executivedominant board of directors, limit minority stockholder protection, and cross-stockholding for the formation of manager-centric corporate governance and industrial interfirm networks.

- The Ministry of Labour ([sic] - currently the Ministry of Health, Labour [sic] and Welfare - MHLW) implements the irrational dismissal principle to help maintain long-term employment practices.

- The Ministry of Health and Welfare (currently the MHLW) administers the multilayered pension system, composed of national, sectorspecific, and firm-specific entities, to aid in the consolidation of firm loyalty among workers.

Institutions are hard to change for at least two reasons. The first hinges on the built-in stability derived from institutional bundling and the publicprivate linkages mentioned above. If one tries to change part of an institution, the other parts of the institution constrain the change. Likewise, if public officials try to change private arrangements by altering public policy, private agents may resist the change, and vice versa, in order to maintain complementarity. The second reason is closely related to the first: institutions involve vested interests. If public officials try to change public policy in an attempt to induce change in private arrangements, holders of vested interests, who believe it will hurt those interests, will veto the policy change.

Core members of the governing coalition, who provide stable support for the party constantly in power, often hold vested interests. A governing 
coalition may be class or sector based. Rogowski (1989) assumes that the governing coalition is class based and is composed of groups and individuals who hold abundant production factors (capital, labor, or land) within the state. These factors may move across industrial sectors as the sectors wax and wane in the wake of their shifting comparative advantages. Due to their mobility, abundant factors govern the national economy and form a dominant class. In the scholarship of political economy, such class-based coalitions are consistent with Marxism and the Heckscher-Ohlin theory of international trade.

In contrast, a sectoral coalition emerges as technological sophistication reduces the cross-sector factor mobility. At a high stage of technological development, expertise and know-how appropriate for one sector may not be useful for another, discouraging factor-holders from moving across sectors and compelling holders of different factors to cooperate with one another within separate sectors (Hiscox, 2002). This type of economic coalition accords with the Ricardo-Viner theory of international trade.

In the early Meiji era (1868-1880s), because the Japanese economy was still agrarian, land was the dominant factor of production, while landlords were the principal members of the governing coalition for the oligarchic government that financed its coffers primarily through land taxes. As mercantilist capitalism burgeoned in the 1890s under the competitive international order, capital owners became increasingly influential and colluded with landlords. As a result, the capital-land coalition reigned from the late nineteenth century through the end of World War II. In the postwar occupation period, the capital-land coalition collapsed because of the Supreme Commander for Allied Powers (SCAP)-led zaibatsu ${ }^{1}$ liquidation and agrarian reform. These reforms improved the socio-political status of labor with an uninvited effect of emboldening militant workers and stoking class conflict. However, the conservatives banded together and restrained labor, leading to a class compromise in which regular employees of large firms with managerial prospects joined the capital-land coalition, tipping the socio-political balance in favor of the conservatives (Gordon, 1988).

Under the order of embedded liberalism that regulated postwar international commerce, the Japanese industrial economy experienced diversification and technological sophistication along with the institutionalization of the CME. For many reasons, the governing coalition became crosssectoral, composed of bankers, business managers, skilled workers, and farmers, providing stable support for the LDP, which remained in power continuously between 1955 and 1993.

Both in general and in the specific case of Japan, institutions gain staying power and legitimacy. Thus, the concept of path dependence is useful for explaining the resilience of institutions. However, as indicated 
above, institutions change over long periods with coalitional changes despite their presumed stability. In this book, the concept of path dependence is reinterpreted as the logic of a punctuated equilibrium in which an institutional reform is precipitated by change in international order. The mechanism of change is conditioned and constrained by the politics of the governing coalition, which influence policy authority allocation and the governing party's motive.

\subsubsection{Globalization and Institutional Rebundling}

Institutions are pressured to change due to exogenous forces, endogenous forces, or both. Either public or private agents, depending upon the specific policy domains, may drive an institutional reform, which means a reciprocal change between public policy domains and private arrangements. It can be stated with a high level of confidence that the pressure for institutional reform in contemporary Japan is derived largely from an exogenous force globalization, which thrives under the neoliberal order.

Globalization is defined as 'a process of removing officially imposed restrictions on movements of resources between countries in order to form an "open" and "borderless" world economy' (Scholte, 2005, p.56). Economically, liberalization means market-driven and marketaccommodating changes in institutions, releasing the market economy from political public control and turning it over to private contracts. Processes and outcomes of liberalization in advanced democratic states take different forms and proceed at different rates due to the effects of various institutional arrangements interacting with exogenous events and endogenous challenges. Liberalization is often associated with an arrangement to inform related agents of policy benefit, to mitigate its negative effect on a particular sector, or both, depending on the nature of the policy change.

Economic organizations are more sensitive to globalization than governments, because they are unable to survive once they fail to adapt to the changing global rules and practices. However, renegotiations over existing institutions or institutional rebundling in the wake of globalization are often difficult mainly due to the rigidities associated with themselves and vested interests within political organizations, as discussed earlier. Under institutional bundling with multiple policy domains, public officials who seek to change institutions through public policy change need to employ a novel technology, depending on the nature of the relationship between policy domains.

There are two classes of cross-domain relationships. One is that an increased payoff in one policy domain may be enhanced by a simultaneous 
increase in another policy domain. This type is complementary. The second is if an increased payoff in one policy domain may be reduced by a simultaneous increase in another policy domain. This type is substitutive. If unrelated, they are said to be independent. In this book, independence is considered part of complementarity without a loss of logical consistency. The appropriate adjustment mechanism depends on whether a policy change involves a complementary or substitutive relationship between policy domains. A more detailed exposition is offered in the next section.

\subsection{TWO MECHANISMS OF ADJUSTMENT}

\subsubsection{Promoting Adaptation through Information Transmission}

A complementary relationship seems relatively easy to manage; rational bureaucratic officials in different policy domains can achieve desirable policy changes through reciprocity. However, they cannot do so singlehandedly, if the officials are bound rationally in that they have imperfect information on others' policy domains and are unable to conduct efficient communication and learning. In the absence of efficient cross-domain communication, boundedly rational officials would be unaware of policy changes in other domains. Even if a policy change did occur, they would be hesitant to pursue a policy change in their own domain for fear of being excluded (i.e., uncertainty about a complementary effect from another domain). For North (1990), this type of policy (institutional) change is an informational problem of belief selection under uncertainty. Due to their limited information-processing ability, boundedly rational officials have to rely on an innovative communication method to determine what and how to change.

Table 1.1 shows a game of stag hunt or assurance that analyzes the above informational problem. Suppose that a proposed institutional reform in the wake of globalization is derived from policy changes in Domains 1 and 2 from the protection equilibrium $(1,1)$ in the lower right cell to the liberalization one $(2,2)$ in the upper left cell. Let us assume that both agents can jointly avoid asymmetric responses in the upper right and the lower left cells since neither cell is a Nash equilibrium. Each response means the collapse of institutional bundling and thus, can be avoided even by boundedly rational agents.

In the game, there are still two Nash equilibria in the upper left and lower right cell, meaning that Agents 1 and 2 might achieve either one of the equilibria. Even though they recognize that they would be better off by choosing liberalization jointly, they might remain in the inefficient 
Table 1.1 Policy change, informational uncertainty, and adaptation

\begin{tabular}{|l|l|c|c|}
\hline & & \multicolumn{2}{|c|}{ Agent 2 } \\
\hline & Domain 1/Domain 2 & Liberalization & Protection \\
\hline \multirow{2}{*}{ Agent 1 } & Liberalization & 2,2 & 0,0 \\
\cline { 2 - 4 } & Protection & 0,0 & 1,1 \\
\hline
\end{tabular}

protection equilibrium due to uncertainty about a policy change in other domains. For instance, even if Agent 1 chooses liberalization, Agent 2 without such information may be hesitant to pursue the corresponding policy change in his or her own domain for fear of being excluded in an asymmetric outcome. For joint policy changes, each agent needs to convince the other of not just the desirability of the joint changes, but his or her willingness to make a policy change in his or her own domain.

One prominent mechanism to achieve an efficient equilibrium in a staghunt game is 'cheap talk' in the sense of Crawford and Sobel (1982), ${ }^{2}$ which is defined as a sender's (say, Agent 1) costless message to a receiver (Agent 2) about the sender's intended action to induce an analogous cooperative action from the receiver. The solution to the multiple equilibria is primarily informational in that the sender can eliminate the receiver's uncertainty, providing that receiving precise information prompts him or her to undertake a policy change. This informational effort helps the expectations of two agents converge, facilitating joint policy changes. In this case, a policy change is viewed as a process in which agents adapt their beliefs and behavior to a new equilibrium. In this book, the mechanism of such a policy change is viewed as adaptation.

According to Aoki (2000, pp.24-5), this type of adaptation process ensues if, and only if, a system of predictive and/or normative beliefs helps guide agents' learning, realizing a new pattern of play, which becomes collectively recognized as how the game is now being played. From this perspective, cheap talk is a mechanism to assist such collective recognition. For North (1990, pp. 80-81), information facilitation promotes the adaptive efficiency concerned with 'the willingness of a society to acquire knowledge and learning, to induce innovation, to undertake risk and creative activity of all sorts, as well as to resolve problems and bottlenecks of the society through time'. The adaptive efficiency can be improved through 'the development of decentralized decision-making processes that will allow societies to explore many alternative ways to solve problems'. The decentralized decision-making approach stressed by North is viewed as 
being equivalent to bureaucratic delegation, which is discussed in the next section.

The postwar Japanese political economy is replete with instances of inter-ministerial cooperation that can be considered as adaptation. For instance, although initially reluctant, the MOF approved a shift in the foreign exchange regime from an adjustable peg to floating in February 1973 (Nakamura, 2012, pp.747-52). This quickly led to private expectations for the eventual appreciation of the Japanese yen in relation to the US dollar and other major currencies. To reduce foreign exchange risks, Japanese export firms felt it necessary to invest abroad. But, to do so, they needed extra capital, some of which needed to be denominated with foreign currencies. The MITI proposed an amendment to the Commercial Code that would permit Japanese firms with high financial credentials to issue convertible corporate bonds, facilitating their risk diversification. In this case, bond market liberalization complemented foreign exchange liberalization as a result of inter-ministerial communication between the MOF and the MITI.

\subsubsection{Promoting Coordination through Coasian Bargaining}

In a second case, the inter-domain relationship is substitutive in that bureaucratic officials in separate policy domains have divergent interests. Hence, the more specialized the officials are in their policy tasks, the more they invest resources to pursue their own tasks, increasing the likelihood of reducing others' payoffs. The inevitable effect is an increase in the negative externality costs. Although specialization may increase adaptive efficiency gains, it may also create a condition for coordination failure.

This problem of coordination with divergent interests is modeled as a battle of the sexes game, as depicted in Table 1.2. In the game, a shift from the protection equilibrium $(1,2)$ in the lower right cell to the liberalization equilibrium $(a, 1)$ in the upper left generates a distributive conflict between the two agents $(\mathrm{a} \geq 3)$. Agent 2, who incurs a loss, opposes the shift. On the contrary, Agent 1 does the same for the opposite shift from the upper left to the lower right cell.

A prominent solution to a coordination problem with divergent interests is to ask for consent and offer compensation to the agent who is expected to lose from a proposed change. According to Aoki (2000, pp. 24-5), this coordination process can converge if, and only if, agents' new action choices based on such expectations generate satisfactory payoffs for both. Satisfactory payoffs for the liberalization shift can be achieved when Agent 1 offers compensation $\mathrm{c}(\mathrm{a}-1>\mathrm{c}>1)$ to Agent 2. This compensatory solution is equivalent to Coasian bargaining in the sense of Coase (1960) 
Table 1.2 Policy change, distributive conflict, and coordination

\begin{tabular}{|l|l|c|c|}
\hline & & \multicolumn{2}{|c|}{ Agent 2 } \\
\hline & Domain 1/Domain 2 & Liberalization & Protection \\
\hline \multirow{2}{*}{ Agent 1 } & Liberalization & a, 1 & 0,0 \\
\cline { 2 - 4 } & Protection & 0,0 & 1,2 \\
\hline
\end{tabular}

Note: $\quad \mathrm{a} \geq 3$.

whereby agents coordinate their choices through arbitration by a third party.

In the real world, a compensatory program often fails due to the lack of credibility or high transaction costs. In order to be effective, both agents must view a compensatory solution as a credible and efficient transaction. This requires a central command that coordinates the agents' behaviors. The central command's role is one or both of the following. For one, it punishes an agent for failing to fulfill the compensatory obligation necessary to secure credibility. For another, it helps reduce transaction costs to induce a voluntary transaction between agents. In both cases, the central command takes on a hierarchy capable of monitoring agents' behavior and realigning their incentives with joint actions. Both agents may submit to this authority because they realize that, in the long run, they will be better off in a system with the authority to impose coordination on them. Conversely, a central command is likely to exist due to the inability of agents to coordinate their actions by their own efforts.

In 1993, GATT signatories were about to reach a historic agreement to conclude the Uruguay Round that would launch sweeping trade liberalization over commodities, agriculture, and services, and would newly initiate trade-related property rights protection. A major snag was the dissent from Japanese agriculture, which was expected to lose because of its relative productive inefficiency. In contrast, internationally competitive Japanese industries were expected to gain greatly from the set of proposed measures, indicating a large interest divergence and distributive conflict between the two sectors within Japanese society. To achieve an efficient solution for its own and the world economy, the Japanese government decided to offer a large-scale compensatory package of up to 6 trillion yen (presumably paid from the industrial earnings) to the agricultural sector in order to obtain its consent and avoid the humiliation of subverting a monumental international agreement. This quid pro quo deal is archetypal Coasian bargaining supported by a central political authority. 


\subsection{POLICY AUTHORITY ALLOCATION AS A STRATEGIC VARIABLE FOR INSTITUTIONAL REFORM: NORMATIVE ANALYSIS}

The previous section discussed the mechanisms of adaptation and coordination to solve informational and distributive problems concerning a policy change. Solutions to the two problems require different techniques and the human talents of public officials - bureaucrats and politicians. In general, bureaucrats have greater policy and administrative expertise in collecting and analyzing information, while politicians are more sensitive to a distributive problem and can take a commanding position to direct compensation or coercion to solve the problem.

To promote policy change through the mechanisms defined above, the government needs to build effective 'authority allocation schemes' that take advantage of the distinct human talents and incentives that are defined in greater detail in the next section. In other words, the authority allocation scheme determines the division of roles between political leadership and bureaucracy, thus influencing their incentives and behaviors. One scheme, referred to as political command, prioritizes the leader's policy authority over bureaucracy. Political command enables leadership to initiate new policy programs, change old ones, and guide bureaucracy's behavior accordingly. Another scheme, referred to as bureaucratic delegation, means that leadership delegates policy authority to the bureaucratic agency with formal jurisdiction over a particular policy domain. It incentivizes the agency to acquire further information and expertise to make professional decisions (Table 1.3).

An authority allocation scheme is a major facet of the government structural architecture. The structural approach to a policy change has international connections since an institutional reform means the adjustment of the state's economic institutions to the international order. There are at least two international relations theories that account for a change in national economic institutions. These theories place varying emphases on the informational and the distributive problems discussed earlier and

Table 1.3 Policy change, adjustment mechanism, and authority

\begin{tabular}{lll}
\hline \multirow{2}{*}{ Policy Task } & Type 1 & Type 2 \\
\cline { 2 - 3 } & Complementary & Substitutive \\
\hline Problem & Informational & Distributive \\
Authority allocation & Adaptation & Coordination \\
\hline
\end{tabular}


propose distinct international solution approaches with the corresponding national authority allocation schemes.

One prominent theory, known as 'transgovernmentalism' (Raustiala, 2002; Slaughter, 2004), views the policy adjustment problem essentially as informational and finds that decentralization is appropriate. The theory holds that globalization is driven by a set of highly technical international rules that are accessible only to specialized bureaucratic officials. It assumes that public-spirited bureaucratic officials can learn and build 'best practices' in competitive settings through transgovernmental networks and then take advantage of the fruits of globalization by adapting the state's policy domains to the international rules. For efficient policy adaptation, the government needs to delegate policy authority to the specialists for policy adaptation.

The other theory of international cooperation, known as 'intergovernmentalism' (Keohane and Nye, 1977), views an adjustment problem as distributive and finds centralization appropriate. Globalization and the related institutional reforms necessitate the aggregation of diverse domestic interests into well-ordered preferences, the negotiation with foreign counterparts, and creation of formal international agreements for policy cooperation, all of which can effectively be promoted by coherent political leadership through international commitment and formal legal processes.

In sum, the decentralized structure suggested by transgovernmentalism provides bureaucracies with policy autonomy and incentives for furthering their specialization and information useful for adaptation. In contrast, the centralized structure suggested by intergovernmentalism strengthens the authority of the political leadership and empowers its ability to coordinate bureaucracies' behavior. In both theories, the government structural architecture is important, especially for a non-liberal state, such as Japan, which stresses the role of public policy in economic growth and the distribution of the fruits of growth across society. In the remainder of this section, I will discuss individual incentives and organizational foundations of the two structural approaches and their international connections.

\subsubsection{Decentralization and Bureaucratic Delegation}

\section{Individual incentives}

As argued thus far, primary actors in a decentralized government are bureaucratic officials who are provided with specific policy tasks in predetermined areas of competence. According to Wilson (1989), bureaucratic officials are interested in their professional reputation in the eyes of their peers by showing their administrative and policy competence. They are also interested in personal career promotion within their bureaucratic 
ministries by contributing to the organizational goals. They have longterm employment contracts and are rewarded with promotions for their contributions to the organizational goals, which are often measured on a reputational basis. These arrangements encourage bureaucratic officials to nurture long-term policy perspectives, making their personal career goals largely consistent with the organizational goals.

If given the task of adjusting their policy domain to international norms and rules, bureaucrats employ incremental adaptation because under institutional bundling a radical policy change in their domain might cause irreparable damage to social trust and related private arrangements and thus to their personal and organizational reputation. Thus, cautious bureaucrats are averse to such a radical policy change, and instead seek gradual adaptation of the existing policy domain, securing policy consistency and institutional complementarity. This line of argument accords with the incrementalist policy-making thesis embraced by Lindblom. According to Lindblom (1979, p. 523):

[D]espite the absence or weakness of central coordination of the participants, their mutual adjustments of many kinds (of which bargaining is only one) will to some degree coordinate them as policy makers. In many circumstances their mutual adjustments will achieve a coordination superior to an attempt at central coordination, which is often so complex as to lie beyond any coordinator's competence.

\section{Bureaucratic organizations}

In general, bureaucratic independence and a decentralized structure ensure informational and policy incentives. Heterogeneity in government promotes intellectual diversity, nurturing the ability of learning for policy adaptation. Particularly, in a changing international environment, bureaucracies must be able to adapt to new policy arrangements, which means that individual ministries' and agencies' tasks must be continuously redefined and enhanced for efficiency. In the age of globalization, the need for information and expertise is particularly strong. Furthermore, because globalization is promoted and regulated by a multitude of highly technical international rules, government is urged to engage in global rule-making and adapt public policy domains skillfully to these international rules. Bureaucrats rather than elected officials have the information and expertise necessary for such rule-making and policy adaptation, but bureaucrats must be incentivized to improve information-processing and policy-adaptation capabilities by being delegated policy authority and stimulated in their careers. 


\section{Rigidity of a centralized government}

The decentralization thesis is based on the assumption that the centralized, top-down and monopolistic nature of government is at the core of governance problems. The associated assumption is that a more decentralized and deconcentrated government can be both more efficient and more flexible to policy adaptations faced by a contemporary government. This approach to governing devalues coordinated and central responses to policy problems in favor of a flexible and entrepreneurial response that also may be sensitive to particular demands (Peters et al., 2000). The decentralization thesis is supported by both theory and practice as follows.

Theoretically, Hayek criticized the faith in centralized decision-making: 'Knowledge which we use never exists in a concentrated or integrated form but solely as dispersed bits of incomplete and frequently contradictory knowledge, which all the separate individuals possess' (Hayek, 1945, p. 517). He continued:

If we can agree that the economic problem of society is mainly one of rapid adaptation to changes in the particular circumstances of time and place, it would seem to follow that the ultimate decisions must be left to the people who are familiar with these circumstances, who know direct of the relevant changes and of the resources immediately available to meet them. (Ibid., p. 524)

Weber (2009) followed by arguing that expertise becomes a power base: 'Every bureaucracy seeks to increase the superiority of the professionally informed by keeping their knowledge and intentions secret' (p. 233). Thus, government necessarily entails dual authority - a formal hierarchical authority and the authority of expertise. The appropriate authority allocation scheme lays out the two types for maximal effectiveness. Nonetheless, it seems that Hayek and Weber would agree that bureaucratic experts are in a position to direct policy adaptation in a knowledge-based society.

Lindblom (1979) argues in the context of Weberian rational-bureaucratic authority that, in a pluralistic decentralized government, no single monolithic elite controls government and society, but multiple elites compete and bargain or muddle through for control and state interests. Lindblom's rational evolutionary perspective accords with polyarchy or pluralist democracy advanced by Dahl (2006). Peters et al. (2000), who observed administrative changes in many advanced industrial countries during the past several decades, have concluded that despite a number of different trajectories and various foundations, one dominant pattern has emerged from those changes in pursuit of political and administrative controls away from the political center of government. Reforms tend to decentralize power among the levels of government, and consequently, diminishing power at the political and administrative centers. Thus, the logic of control in the 
public sector has switched from a hierarchy and toward competition and mutuality (see Hood et al., 2004).

\section{Transgovernmental networks}

In the age of globalization, the decentralization thesis has recently been integrated into the international relations theory of transgovernmentalism (Slaughter, 2004; Kingsbury et al., 2005). The theory postulates that bureaucratic officials engage in domestic and international processes of muddling through with their foreign counterparts in order to reduce the gaps between legal and national jurisdictions, leading to the creation of transgovernmental networks. According to Slaughter (2004, pp. 3-4), such networks have several common functions across various issue areas: among other things (1) to 'expand the regulatory reach' that help governments close the gaps between their jurisdictions; (2) to 'build trust and establish relationships' among their participants, which are 'conditions essential for long-term cooperation'; and (3) to facilitate regular information exchanges and develop 'databases of best practices'. Essential to policy adaptation in a globalizing world are shared expert knowledge, comity, and mutual trust among domestic and international bureaucratic officials.

The structural foundation of transgovernmental networks is a 'disaggregated state', or a sophisticated administrative state with the separation of powers and specialized bureaucratic agencies. In such a disaggregated state, legislative, bureaucratic, and judicial actors already have the legal power and authority delegated by the state's political leadership - as well as the initiative and capability - to enter into such relationships with foreign counterparts. From this perspective, globalization is a derivative of transgovernmental networks. Accordingly, specialized agencies are the ones that adapt the states' policy domains to international rules and practices.

\subsubsection{Centralization and Political Command}

\section{Individual incentives}

The thesis of centralization is in direct contrast to that of decentralization with respect to the theory of governance and globalization. There are two perspectives on the incentive of political leadership. One is an elitist perspective in which leadership is in a position to define the 'national interest' and pursue it as their career objective in the form of a policy platform (Schumpeter, 1976). In popular democracy, it is the electorate, who presumably support their policy platform, that choose their political leaders. To implement the platform, political leaders have the constitutional power to (1) initiate policy programs by directing bureaucratic officials to take 
certain actions; (2) exact obedience; (3) monitor bureaucratic behavior; and (4) reward good and punish bad behavior.

The other is a pluralistic perspective in which a state's preference and policy are aggregated from individual and group preferences through democratic processes, but the policy outcomes depend crucially on which individuals and groups are represented through formal and informal political processes (Dahl, 2006). With pluralistic public preferences, interest aggregation is a crucial governing function to generate sensible public policy. Policy behavior is determined by the relationship between individuals and groups, which is arbitrated by public officials through the state's legislative, administrative, and adjudicative institutions.

The elitist and pluralist perspectives are in frequent conflict but can be made compatible in the following sense. Suppose that leaders initiate a policy change as part of their platform. However, the change produces shocks to the policy domains that were predetermined by interest aggregation, generating losses for certain groups of individuals and gains to others. Sensitive to the distributive effect, leaders take the appropriate response to reduce losses and maintain gains, in order to re-establish the balance of interests and policy consistency. The extent of compensation is determined through political bargaining, and such a compensatory act constitutes coordination that helps the relevant actors' expectations converge, making policy change acceptable to them. Such a balanced response requires sensitivity, coherence in government, and a central command.

\section{Central organization}

A centralized political authority has an advantage over decentralized bureaucracies - it has a superior ability to make bureaucracies' policy behaviors mutually consistent. Centralization can reduce coordination failures, permitting a single leader to command the actions of all bureaucracies in the government. In other words, the central leadership coordinates different bureaucracies to resolve frequently occurring conflicts between tasks.

However, centralization comes at the price of costly communication and reduced agency discretion and initiative, which lower the benefits of specialization that accrues in a decentralized government. Centralization means higher costs of communication than in decentralization. With the reduced agency initiatives and specialization, a government becomes unable to adapt its policy domains and the economic institution to changing international rules. In general, a large policy change demands coordination, and thus centralization. A drawback of centralization may be an adaptation failure. 


\section{Globalization and the virtue of centralization}

As globalization deepens the extent of policy adjustment shocks (frequency and scale), governments must improve their coherence and central command. From the intergovernmentalist perspective, legal formalism and political accountability are at the core of a policy change (Keohane and Nye, 1977). To promote a change at the international level, a treaty should be negotiated and agreed upon by political leaders accountable to the public with the help of professional diplomats and regulators. The agreedupon treaty needs to be ratified and enacted by the legislature into a body of law that gives the government's regulatory agency the legal mandate to enforce it under executive and legislative supervision. Deviation from the treaty needs to be adjudicated by the judiciary to secure treaty compliance.

In this view, transgovernmental regulatory networks alone are insufficient to generate legitimacy, adjustment, and compliance. The political theory behind a policy change is not that the state is disaggregated and bureaucrats have the intrinsic power to coordinate with their foreign counterparts, but rather that the cabinet or executive branch, to which the bureaucrats are subservient, has the ability to set, on behalf of the state, the terms on which bureaucrats deal with their counterparts (Anderson, 2005, p. 1285). 'Much of [network] activity arises under the shadow of an intricate web of obligations arising from obligations assumed under treaties and international organizations' (Alvarez, 2001, p. 211). Informality associated with regulatory agreements detaches these state bureaucracies from the process of enforcing international regulatory standards. To secure adjustment and compliance, political leadership ought to take central control and lead policy coordination. Formal international treaties provide leadership with authority and legitimacy in meeting treaty obligations, which means adjustment to the international order including treaties. At the same time, treaties serve as commitment devices that prompt leadership to comply with treaty obligations; non-compliance creates external and internal audience costs that hurt the leadership's credibility and political support. In turn, leadership seeks to negotiate and conclude international treaties strategically in order to pursue a policy change, defeating opposition from special interests and bureaucratic politics.

\subsection{CONCLUSION: STRUCTURAL DILEMMA, MANIPULATION, AND FLEXIBLE AUTHORITY ALLOCATION}

The political leadership highlighted here is the one imbued with democratic governance in which the public chooses the officials of political 
organizations via competitive elections. These officials are in a position to envision the 'national interest', configure the government structure, and define the division of roles between political and bureaucratic officials in order to facilitate the appropriate mechanism of adjustment, either adaptation or coordination, in pursuit of the national interest. Normatively, democratic governance with either a decentralized or centralized structure restricts the oligarchic or rent-seeking behavior of public officials in pursuit of their own policy goals or patronage for their clients.

The analysis in this chapter implies that the government structural architecture involves a dilemma. On the one hand, the political command associated with a centralized structure is appropriate for control and coordination, but is likely to stifle policy adaptation because its central authority discourages bureaucratic officials from pursuing specialization and personal or organizational initiatives. On the other hand, the bureaucratic delegation associated with a decentralized structure is appropriate to promote the information and expertise necessary for communication and adaptation, but is unable to compel reluctant agencies to undertake costly coordination due to the leadership's reduced capacity to punish, reward or persuade them. Hence, an optimal architecture that can effectively deal with all types of institutional reforms is difficult to obtain.

In addition to the structural dilemma, self-centric public and private actors often hinder the choice of an appropriate structure. That is, influential groups in and out of government can manipulate the government structure to promote their own and their clients' interests. These groups seek to design a structure to ensure that their interests are well protected and carried out over time. That is, they seek to embed their particularistic interests into the structure (Moe, 2005; Aoki, 2010, p. 234).

In the age of globalization, policy authority allocation should be made strategically and flexibly based on an expansive set. In summary, this chapter shows that policy authority allocation is a frequent target of political contestation. The next chapter analyzes the government structural architectures empirically in the context of Japanese politics.

\section{NOTES}

1. A large Japanese business conglomerate.

2. Schelling (1960, pp.57-9) argued that a focal-point effect can promote cognitive adjustment to an efficient equilibrium, but did not specify how to produce such an effect. 